\title{
The Driving Factors and Focus of CSR Implementation: A Comparison of Family Business in Indonesia, Japan, and Thailand
}

\author{
Sari Wahyuni ${ }^{1 *}$, Arif Ario Suryo Hendara Sentanu ${ }^{2}$ \\ ${ }^{1}$ Faculty of Economics and Business, Universitas Indonesia, \\ Email: sari.whyn@gmail.com \\ ${ }^{2}$ Debt Research, PT Danareksa Sekuritas
}

\begin{abstract}
The purpose of this study is to understand what are the driving factors and focuses of Corporate Social Responsibility (CSR) implementation by family businesses (Indonesia, Japan, and Thailand). We investigated how three countries differ and alike. By employing qualitative research, we conducted thorough literature review and in-depth interviews with several family businessmen from Indonesia and Japan. The result of the study showed that culture, religion, moral and ethics are the driving factors for family businesses. In Asia, family businesses focus their CSR program on education, community, and the environment. Despite the similarities, each business had their own characteristics which made the difference among the enterprise. In Indonesia, ethics and religion are the major driving factors for CSR implementation. In Japan, Confucian philosophy and ethics are their main reason. In Thailand, Buddhism as it is the foundation of the culture and norms in Thailand apparently become the major driving factor for CSR implementation.
\end{abstract}

Keywords: Corporate Social Responsibility, CSR, Family Business, Family, Business, Indonesia, Japan, Thailand.

\section{Introduction}

The rise of privatization has reduced the role of government in achieving societal goals, including the intent to achieve the MDG's (Millenium Development Goals). Therefore, corporations must take greater responsibility toward society and help them to achieve societal goals. It is not weird that there is a growing public concern that private corporations should not only seek profit as much as it can, but it should also operate as good corporate citizens and socially responsible organizations that benefits its stakeholders. CSR has a huge impact towards society. Although it is the duty of the government to fulfill the basic needs of its people, they are unable to fully execute it. Therefore, CSR programs can help empower communities that are lacking basic needs.

Philips CSR program has brought access of electricity to villagers in South Sulawesi (Wiradji, 2015). Google's Project Loon brings Internet to remote areas around the globe (Tierney, 2015). These are just examples of the huge impact corporations towards society development. With the economic power shifting towards Asia, we must then try to understand how this economic growth can benefit the society particularly in Asia and help them to achieve basic societal needs. This means CSR has become an important part of the operations of corporations. 
The objective of this study is to increase our understanding on how and why family businesses implement CSR program. Family business is a firm where a family owns a significant part of its capital, and that family has significant control over the company, and a member of the family holds a management position within said firm.

There are several reasons why family business is an interesting area to be researched. First, Worldwide family businesses account for $75 \%$ of the top 100 companies (Panjwani, Anggarwal, \& Dhameja, 2008). This shows how big family owned businesses are. Second, family businesses are the backbone of the economy in many countries. This cannot be truer than in Asia, where 70\% of firms are family owned and across 10 Asian markets, represent $32 \%$ of total market capitalization(Raharso, 2012). Third, in Indonesia, over $90 \%$ of firms are family owned business and controlled operation.(Handoyo, 2010). In Japan, the percentage of family business is also over $90 \%$.(Oi, 2012) This implies that family businesses play an important role towards the economy of a country, specifically in Asia. Family businesses can play a key role and have a greater impact toward societal issues including achieving the MDGs.

This leads to the main research question, which is: "How do CSR by family business differ between Indonesia, Japan, and Thailand?" We strive to answer several sub-questions:

1. Does family business in Indonesia, Japan, and Thailand implement CSR?

2. What are the main driving factors of CSR implementation within Indonesia, Japan, and Thailand?

3. What are the focus/concern of CSR implementation in Indonesia, Japan, and Thailand and how do they differ?

This paper began with the literature review. The second part consists of the research methodology. The third part presents the study findings and discussions. The final part of the paper derives conclusions of the research.

\section{Literature Review}

There are many understandings regarding CSR. CSR may include the following: A company running its business responsibly in relation to internal stakeholders (shareholders, employees, customers, and suppliers); the role of business in relationship to the state, locally and nationally, as well as inter-state institutions or standards; and business performance as a responsible member of the society in which it operates and the global community(Wartini \& Heriyanto, 2014). Amaan, Jaussaud, \& Martinez (2011) state CSR policy as "a business organization's configuration of principles of social responsibility, processes of social responsiveness, and policies, programs and observable outcomes as they relate to the firm's societal relationships"(Bruno, Jacques, \& Isabelle, 2011). The World Business Council for Sustainable Development defines CSR as "the continuing commitment by business to behave ethically and contribute to economic development while improving the quality of life of the work force". However, the essence of CSR involves companies going beyond their own interest and legal obligations to recognize responsibility for the impact their business practices, policies, and corporate identities may have on its stakeholders, society, and the environment(Valenti, Carden, \& Boyd, 2014). 
As stated in previous research by Bruno, Jacques, \& Isabelle (2011), the definition of family business must include 3 dimensions:

i. One or several families must hold a significant part of the capital

ii. Family members must retain significant control over the company, including over the distribution of capital and voting rights among non-family shareholders, with possible statutory or legal restrictions

iii. Family members must hold top management position

Hence, family business can be defined as firm where a significant part of its capital is owned by a family, and that family has significant control over the company, and a member of the family holds a management position within said firm. Family businesses are a key part of the economic fabric, and their contribution to the GDP is significant. Family businesses make greater effort in developing CSR activities.

To understand why family business implements CSR programs, we must differentiate family business from non-family business. Family business behaves differently from non- family business, in a way the decisions made do not always economically logic. Unlike non-family business where the owners are invisible, family business puts their name on the firm, which means the identity of family members is closely linked to the firm. The public sees the action of a family firm as a reflection of the family itself. Therefore, the perception that the public has on the firm directly affects the reputation and image of the family that owns the firm. It is logical to assume that these family want to control how their firm operate to maintain their reputation. In the words of Gomez-Meija et al. (2011), "personal pride and self-concept of family members tends to be intimately tied to the business". Furthermore, Hirigoyen and Poulain-Rehm (20140 argue that "the founders of family business see it as an extension of themselves and the company reflects their fundamental values".

One factor that can be seen as important is national culture. People who live in certain areas will certainly be affected by the culture of that area. Individuals' values are influenced by a nation's value system, which is outlined by national culture. Individuals' values affect how one perceives and acts towards CSR (Thanetsunthorn). Habisch et al. (2005) argued that national culture plays a significant role as the predictor of societal minds, which had a significant influence towards CSR initiatives and practices (Habisch et al., 2005). Thanetsunthorn (2014) analyzed the effect of four culture dimensions: power distance, individualism, masculinity, and uncertainty avoidance, towards CSR performance in three dimensions: employee, community, and environment, and in four Asian regions: Eastern Asia, Southeast Asia, South Asia, and Asia Pacific. Her study proves that national culture and geographic significantly influenced the CSR performance. Hence, it is safe to assume that the location of the family business and its national culture can have a significant impact towards its CSR initiatives and performance.

An important factor that plays a role in family business is emotion. There is a strong presence of emotion within a family business. As Baron (2008) implies, "It is now widely accepted that the boundaries between the family and the firm are blurred in family business, and that emotions flow back and forth, ultimately affecting how the firm conducts its activities" (Gomez-mejia et al., 2011). Therefore, we can see the inclusion of emotions in the study of the management of family firms in recent years. Many emotional construct has been proposed, such as emotional capital, emotional ownership, emotional returns and cost, emotional value, commitment entrapment, and possession attachment (Gomez-mejia et al., 2011). 
According to Gomez-Meija et al. (2011), "These constructs represent attempts to capture the emotional connection family owners feel for their firms and to portray the organization as a recipient of the family's affective stock, which influences the psychological, behavioral, social, and cognitive aspects of managing the business". Unlike non-family business, family members are stuck to family firms, unable to resolve their emotional issues by just walking away. Therefore, emotions play a strong role in family businesses where exit of key actors may not be a viable alternative (Gomez-mejia et al., 2011).

Another factor that also plays an important role in family business is family value. The way a family business conducts its activities reflects the values that the family upholds. The value of the family is the foundation of the organizational culture of a family firm. According to Astrachan and Jaskiewicz (2008), "the presence of strong family values favors the development of a distinct organizational culture". Moreover, the values and motivations of the family plays as powerful cultural drivers across generations (Gomez-mejia et al., 2011).

Another distinctive aspect of family firms is altruistic behavior among family owners; their desire to cater to the welfare of the family unit. According to Gomez-Meija et al. (2011), "Altruism is presented as a noneconomic aspect of the business, whereby the family owners receive satisfaction by benefiting family employees independent of their relative contribution to the organization or their capacity to reciprocate in kind. Hence, the fulfillment of family obligations based on blood ties rather than competence or demonstrated performance become paramount in family firms" (Gomez-mejia et al., 2011).

All the factors stated above are noneconomic factors that differentiate family business and non-family business. These noneconomic factors can be labeled as "socioemotional wealth" (SEW). The term socioemotional wealth was founded by Gomez-Meija et al. (2007) and can be defined as "non-financial aspects of the firm that meet the family's affective needs" (GomezMejia et al., 2007). Socioemotional wealth plays an important part in explaining why family businesses implements CSR programs.

Socioemotional wealth is the main driver for family firms to conduct its activities in a socially responsible manner. As Berrone, Cruz, and Gomez-Mejia (2012) stated, "family firms are typically motivated by, and committed to, the preservation of their SEW, referring to nonfinancial aspect or "affective endowments" of family owners" (Berrone, Cruz, \& Gomez-Mejia, 2012). SEW therefore represent the pivotal frame of reference that family firms use to make major strategic choices and policy decisions. It is therefore logical that family firms are then willing to preserve their SEW even though it is not economically logical.

Family firms are committed to preserving there SEW. Since they intend to preserve their SEW, the likelihood to invest in PSE (proactive stakeholder engagement) activities is high, even though there is no clear evident suggesting that these activities serve its economic interests. PSE can be defined as "the Willingness of business to anticipate the needs of their stakeholders and develop practices that meet these needs" (Hirigoyen \& Poulain-Rehm, 2014).

Cennamo et al. (2012) see PSE as a firm's "more active stance towards stakeholders by trying to anticipate their needs and develop substantive firm-specific, stakeholder-oriented practices. When SEW becomes the family principals' frame of reference for taking strategic decisions, they will consider the welfare of their stakeholders to a greater extent, and therefore 
are more inclined to favor proactive, stakeholder-oriented activities". This choice reacts to a blend of both instrumental and normative motives that are intrinsically related to the building and preserving of SEW, that could possibly be decoupled from pure economic reasoning.

From an instrumental motive perspective, the implementation of PSE activities is guarantee of the organization's continued existence thru the gains in social legitimacy and enhanced reputation. From a normative point of view, PSE activities may be driven by the family's desire to be a responsible citizen (Cennamo et al., 2012). Hence, the drive to build and preserve SEW would tend to induce family owners to consider the needs of stakeholders and favor care-oriented activities. Therefore, when family principals use gains and losses in SEW as a frame of reference, they are more likely to favor the implementation of PSE activities (Cennamo et al., 2012). CSR activities can be seen as a form of a firm's "proactive stakeholders' engagement" (PSE).

\section{Research Methodology}

As stated in the earlier chapter, this study analyzed how family business in Asia, specifically Indonesia, Japan, and Thailand implement their CSR initiatives. The subsequent paragraphs explain how family business in these countries made it interesting to be researched.

Indonesia has a population of approximately 250 million people. With a GDP of over $\$ 800$ billion in 2014 (The World Bank, 2015), it is the largest economy in South East Asia (British Broadcasting Company, 2015) and is part of the G20(Deutsche Bundesbank). Ever since the 1997 economic crisis, Indonesia has experienced 'miraculous' economic growth. Its average decade growth from 2005-2015 is 5.8\% (Sentana \& Sudrajat, 2015). As stated above, family businesses account for $90 \%$ of all firms in Indonesia (Handoyo, 2010). It is interesting to see how the economic growth in Indonesia affect family businesses' CSR program.

Japan's economy was devastated after they lost World War 2 in 1945. Since then, Japan experienced total reformation, which was emplaced by the Allied nations, led by General Douglas MacArthur who was the Supreme Command of Allied Powers (United States Department of State). This reformation included economic reformation, which introduced free market capitalist system. This made Japan, the first country in Asia to adopt a western type of economic system. Its economy continued to grow which then led Japan to becoming the second largest economy in the world from 1968 to 2010 (Hays, 2013). Although adopting free market capitalist system, Japan's industry is still dominated by large family conglomerates, which are known as keiretsu (Colombo, 2012). By having a western economic system but still dominated by family businesses, it is thus interesting how CSR has evolved and is practiced in Japan.

In 2014, Thailand has a GDP of $\$ 373.8$ billion, with a population of 67.73 million people (The World Bank, 2015). This makes Thailand the second largest economy in Southeast Asia (Asian Development Bank, 2015). Similar to Indonesia, family businesses play a major role in the Thai economy, accounting for up to $62 \%$ of all firms (Panjwani, Anggarwal, \& Dhameja, Family Business: Yesterday, Today, Tomorrow, 2008). It will also be interesting to study CSR by family businesses within Thailand.

This study attempted to understand the motivation behind conducting CSR CSR programs. Therefore, to answer the main question and sub-questions, an explorative study with qualitative research approach was applied. The reason to adopt a qualitative approach is due to the nature 
of the study. The topic of CSR itself, specifically reasons for implementing it or in other words drivers to motivate human to implement CSR is not something that can be quantified. There is no numbers in reasons, it cannot be analyze statistically (Wahyuni, 2015). The study focuses on how and why; trying to understand human behavior and the reasons that govern human behavior, in this case towards the drivers and the process of CSR implementation by family business in Indonesia, Japan, and Thailand. Therefore, qualitative research is the correct approach for this study.

To set in-depth result on the topic we are studying, the data collection consists of two phases.

\section{Stage 1: In-depth Literature Review}

We conducted an in-depth literature review by analyzing various articles related to the topic of the study. These articles are used to create a theoretical background of the study and find answers to the aim of study. Since we aim to conduct a massive analysis on literature review (approximately 100 articles), therefore we used NVivo so that we can find critical variables that influence each country's behavior on CSR. Specifically, word count has been used to find the drivers, challenges, and focus ofCSR within Japan, Indonesia, and Thailand. Nvivo is the perfect tool to assist qualitative research. Qualitative research usually involves evaluating, interpreting, and explaining social issues. Nvivo helps in grouping, categorizing, and finding pattern within a collection of large data, whether it be from literatures or interviews. Nvivo reduces a great number of manual task and gives the researcher more time to discover tendencies, recognizes theme and derive conclusions. There are five important task in which NVivo ease analysis of qualitative data which are: managing data, managing ideas, query data, modeling visually, and reporting (Hilal \& Alabri, 2013)

\section{Stage 2: In-depth Interview}

Besides in-depth literature review, we also conducted in-depth interviews with several family business practitioners from Japan and Indonesia. The reason to include interview within the research process is due to the nature of the study. As stated earlier, this study is trying to understand human behavior. Thus, conducting interview will help gain more insights into the human nature of these family businessmen. An interview provides high credibility and flexibility because interviewees have the freedom to express and explain themselves. It also gives the ability to gain more insights as the interviewer can probe for more details and ensure that the interviewees are interpreting questions the way they are intended to (Wahyuni, 2015).

The unit analyses of this study are family businessmen who are actively involve with their organization. The interviews were conducted in English and Indonesian. Interviews that were conducted in Indonesian were translated into English in the transcript. Due to time and budget limitations, the researchers only conducted interviews with five businessmen, which included one businessman from Japan and four businessmen from Indonesia. Due to time and budget limitations, no interviews were conducted with any businessman from Thailand. The informant of interview holds a top management position within their company. They are either the founder of the company or a member of the family. Their family has majority control of the company. These companies operate in various sectors. All generate revenues in the billions of rupiahs. 


\section{Research Findings}

In the case of Indonesia, a total of 57 academic articles were used in the literature review. The small number of articles being used was due to the limited number of study regarding CSR in Indonesia. A word frequency count was done using NVivo in analyzing articles related to Indonesia

The drivers for CSR in Indonesia are religion, culture that includes values, which is then described by Sharma as gotong-royong, moral, and ethics. The word frequency count showed that religiosity came up 289 times, Islam came up 500 times, Confucian came up 237 times, and Spiritual came up 237 times. Culture and values came up 1014 and 1335 times respectively. It is shown that the highest driver of CSR in Indonesia is culture and ethics.

As seen on Figure 2, the focus of CSR activities in Indonesia are education, community development, and environmental protection. Environment was the highest, coming up 2792 times. Community was the second, coming up 1375 times. Education came up 370 times. Based on the literature review, the highest focus of CSR in Indonesia is Environment. However, this contradicts the interviews which were conducted with Indonesian family businessmen who all stated that their focus of CSR is education.

In the case of Japan, a total of 33 academic articles were used in the literature review. The small number of articles is due to the limited number of study available regarding CSR in Japan.

The same word frequency count was also done with articles related to Japan. As seen on Figure 3, drivers of CSR for family businesses in Japan includes religion, culture, moral and ethics, principles, and Reputation. Moral and ethics came up with 353 and 405 word count respectively. Culture came up with 386 word counts. Religion came up with 323 word counts. Principles came up with 248 word counts. Reputation came up with 233 word counts. It is shown that the highest driver for CSR in Japan is ethics.

The picture above shows the area of CSR activities for Japanese family businesses. These areas include education, environmental protection, and community/society contribution/ development. Activities related to environment came up with 938 word counts. Activities related to society and community came up with 922 and 541 word counts respectively. Activities related to education came up with 297 word counts.

A total of 57 articles were used for literature review. These articles were then analyze using word frequency count in NVivo to determine key variable of CSR by Thai family businesses. The same word frequency count was also done with articles related to Thailand. As seen in the picture above, the drive that leads family businesses in Thailand to conduct CSR are religion, culture, moral and ethics, sense of solidarity and wanting to contribute to society. Religion came up 515 times, with Buddhism coming up 316 times, spirituality 242 times, and Confucian 169 times. Culture came up 1180 times, with values coming up 1538 times. Moral and ethics came up 531 times and 1566 times respectively. Solidarity came up 213 times. Contribute and society came up 489 times and 1598 times respectively. 
Table 1. List of Interview

\begin{tabular}{|c|c|c|}
\hline Name & Position & Overview of Company \\
\hline \multirow[t]{3}{*}{ Ken Shibusawa } & Chairman & Commons Asset Management inc \\
\hline & & Mutual Funds Company with 25 employee \\
\hline & Director & Shibusawa Eichi Memorial Foundation \\
\hline \multirow[t]{3}{*}{ Hariadi Sukamdani } & VP & Sahid Group (Property Developer) \\
\hline & & PT Sahid Jaya International \\
\hline & & Hotel Chain, revenue: +- Rp 200 billion \\
\hline \multirow[t]{4}{*}{ Ahmad Marda } & $\mathrm{CFO}$ & PT Pasaraya Tosersajaya \\
\hline & & Department Store, retail chain \\
\hline & & property development \\
\hline & & Revenue: +- Rp 300-400 billion \\
\hline \multirow[t]{6}{*}{ Kadek Sarjana } & Pres. Dir & PT Titis Sampurna \\
\hline & & Oil and Gas Services \\
\hline & & Inspection and Certification \\
\hline & & Project Management \\
\hline & & Energy Trading \\
\hline & & Property Investment \\
\hline \multirow[t]{5}{*}{ Indra Djokosutono } & Shareholder & Bluebird Group \\
\hline & & Transportation, Logistic, property \\
\hline & Op. Manager & PT Blue Bird Tbk \\
\hline & & revenu: +- Rp 4-5 billion \\
\hline & & number of employees: 3477 \\
\hline
\end{tabular}

Source: Constructed by The Researcher

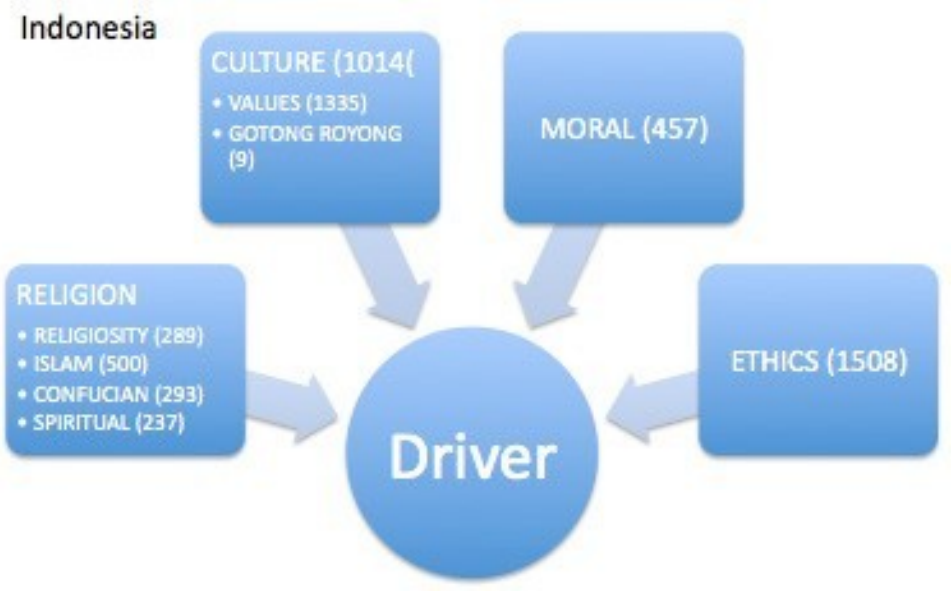

Figure 1. Indonesia Motivating Driver For CSR Implementation 


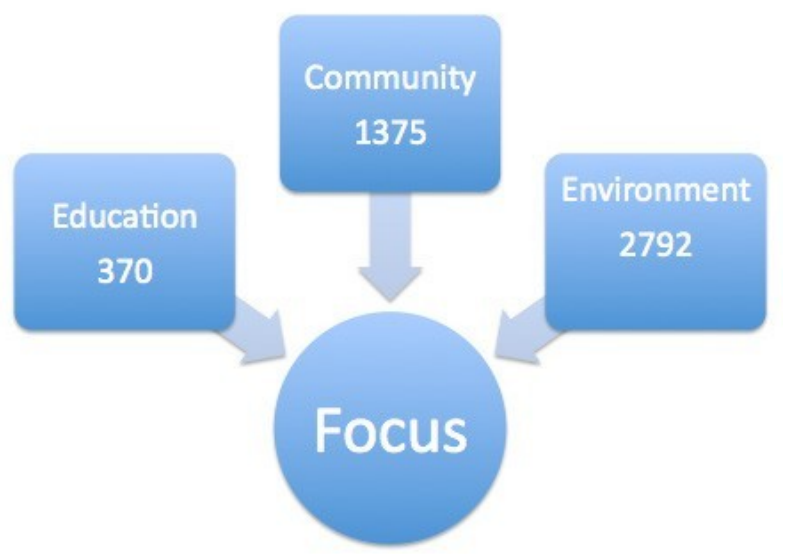

Figure 2. Indonesia Focus of CSR

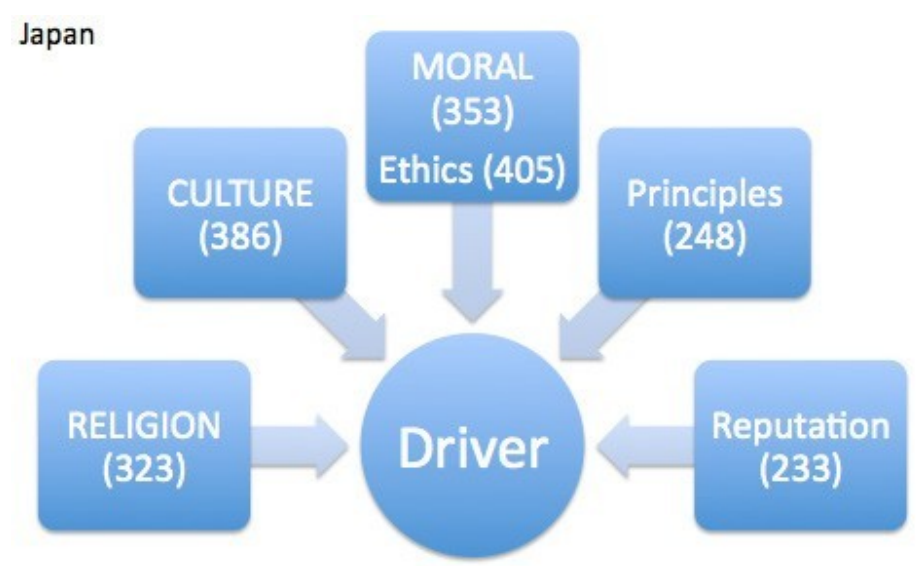

Figure 3. Japan Driving Factors

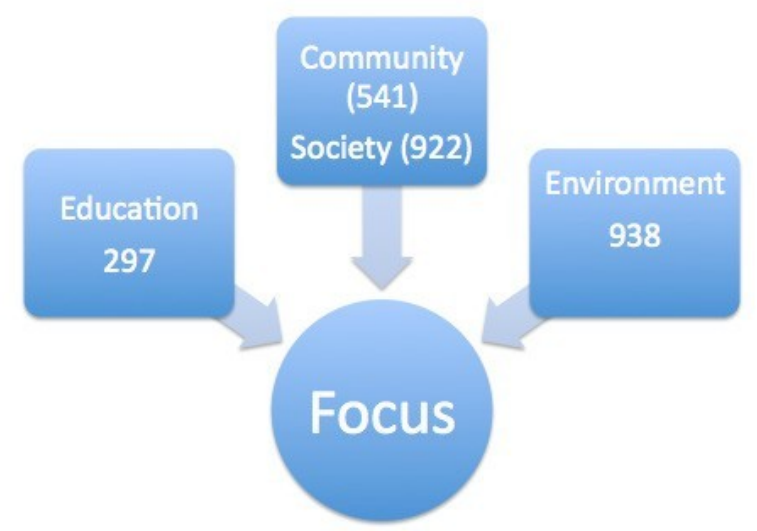

Figure 4. Japan's CSR Focus 


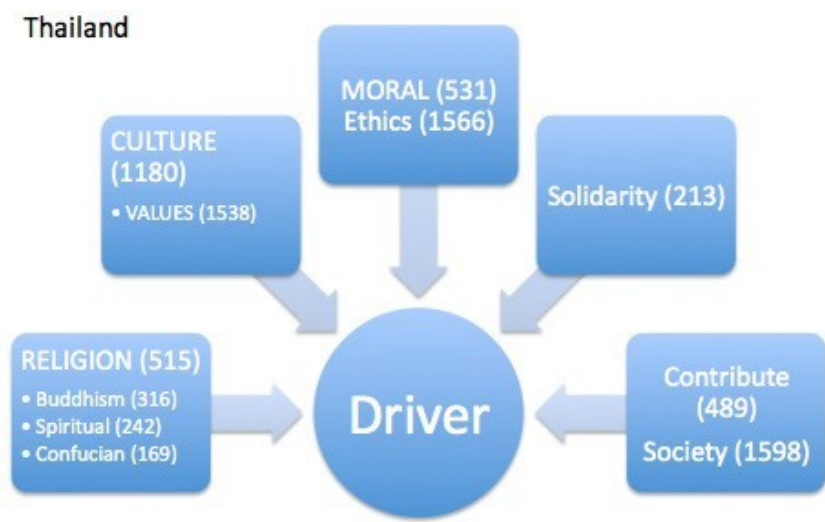

Figure 5. Thailand Motivating Drivers for CSR

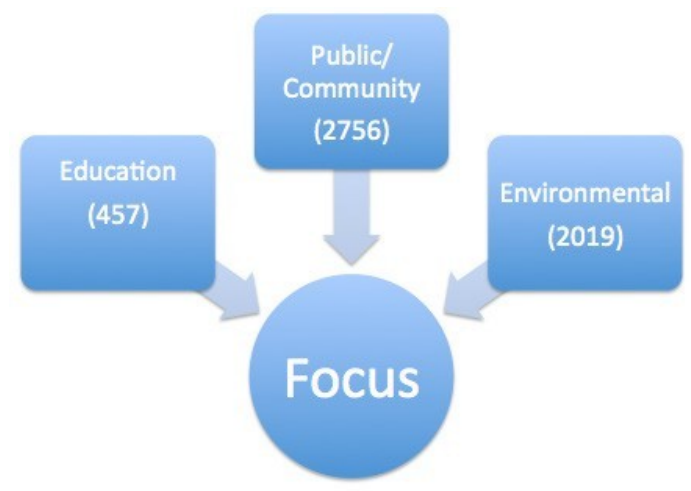

Figure 6. Thailand CSR Focus

Table 2. Comparison of Indonesia, Japan, and Thailand

\begin{tabular}{|c|c|c|c|c|}
\hline & & & & \\
\hline \multirow{3}{*}{ Indonesia } & Religion & 289 & Education & 370 \\
\hline & Islam & 500 & Community & 1375 \\
\hline & Confucian & 293 & Environment & 2792 \\
\hline \multirow{3}{*}{57 References } & Spiritual & 237 & & \\
\hline & Culture & 1014 & & \\
\hline & Moral \& Ethics & 1565 & & \\
\hline \multirow{2}{*}{ Japan } & Religion & 323 & Education & 297 \\
\hline & Culture & 386 & Community & 541 \\
\hline \multirow{2}{*}{33 References } & Moral \& Ethics & 758 & Society & 922 \\
\hline & Reputation & 233 & Environment & 938 \\
\hline \multirow{3}{*}{ Thailand } & Religion & 515 & Education & 457 \\
\hline & Buddhism & 316 & Community & 2756 \\
\hline & Spiritual & 242 & Environment & 2019 \\
\hline \multirow{3}{*}{60 References } & Confucian & 169 & & \\
\hline & Culture \& Values & 2718 & & \\
\hline & Moral \& Ethics & 2097 & & \\
\hline
\end{tabular}

Source: Constructed by The Researcher 
As seen above, the focus of CSR in Thailand consists of 3 areas which are education, public/ community welfare/development, and environmental protection. Education came up with 457 word count. Public/community came up with 2756 words. Environmental came up with 2019 words.

A total of 150 academic papers were analyzed in conducting the literature review. 57 academic papers were used for the literature review regarding Indonesia. 33 academic papers were used to conduct literature review for Japan, 60 academic papers were used to conduct literature review regarding Thailand. Interviews were conducted with five businessmen; one from Japan and 4 from Indonesia. No interview was conducted with businessman from Thailand. This was due to time and budget limitations.

The table above shows the word counts analyzed by NVivo explaining the driving factors and focus of CSR by family business in Indonesia, Japan, and Thailand. Overall, all countries included religion, culture, moral and ethics as their driving factors to conduct CSR. All countries also focused on education, community, and the environment. However, each country has its own unique characteristic within its driving factors and focus of CSR.

In Indonesia, the highest driving factor is culture and moral and ethics. This concedes with the interviews that were conducted with Indonesian family businessmen. They stated that "doing the right thing", which is part of moral and ethics, was the reason why they implement CSR programs. They also stated religion as one of the dominating factor in CSR implementation. The focus of CSR in Indonesia is environment. This contradicts with the interviews. All subject of interviews stated education as their primary focus of CSR. However, a review of several family business shows that their interview includes education, community development, and environmental protection.

In Japan, the dominant driving factor of CSR is moral and ethics. This concedes with what Ken Shibusawa explains as "doing the right thing". The focus of CSR in Japan is environment. However, this contradicts Ken Shibusawa, as he states that his focus of CSR is social entrepreneurship, which relates to community development.

In Thailand, the dominant driving factor of CSR is culture and values, and moral and ethics. The focus of CSR in Thailand is community.

All countries coincide with each other in terms of driving factors, as all having moral and ethics as their driving factor. This may be due to all countries are Asian countries. Some believe that Indonesia and Thailand are from the same root. In terms of focus of CSR, all countries differ each other as based on the interviews, Indonesia focuses on education, Japan focuses on the environment, and Thailand focuses on community development.

\section{Conclusions}

Based on the result of the analysis of data in discussed in the previous chapters, several conclusions were made with regards to the research questions. Family businesses in Indonesia, Japan, and Thailand do implement CSR program. Each country has several driving factors on why they implement CSR program. The factors can be similar but are different in nature. In Indonesia, all but one businessman states that one of the main reason they implement CSR is 
religion. Since all but one businessman are Muslims, this means that the teachings of Islam is highly related to CSR activities and plays a crucial role on CSR implementation in Indonesia. Confucian teachings also play a role as a driving factor of CSR implementation.

The other driving factors in implementing CSR are humanity, morals, ethics, family values, corporate reputation, business sustainability, having good impact on others, purpose of life, and having the power to do good. Some of the factors described can be categorized as part of culture. In Japan, Confucian philosophy plays a role as a driving factor of CSR implementation by Japanese family business. Yet, religion still play an important part on CSR implementation in Japan. As Shibusawa states, "My upbringing was Christianity". Other driving factors also include family values, ethics, morals, beliefs, doing the right thing, which also part of the Japanese culture.

In Thailand, Confucian teachings play a role as the driving factor of CSR implementation. As the largest religion in the country, the teachings of Buddha is also considered as a determining factor of CSR implementation. Other factors include moral, ethics, family values, and social values. Some part of the factors can be described as culture. It is safe to assume that Thai culture plays a role in CSR within Thailand. All countries have similar driving factors in CSR implementation. Those driving factors are Confucian philosophy, religion, and culture.

Although businesses in Indonesia implement CSR in the areas of environmental protection, social/public/community development, the focus of family businesses in Indonesia is education. All businessman interviewed agreed that education is most important and creates the greatest value towards others. In Japan, the focus of CSR activities is in the areas of human resources management, governance, social contribution or development, and environmental protection. In Thailand, the focus of CSR activities is in the areas of environment, education, and public welfare or development. In Indonesia, there are no obstacles in CSR implementation in terms of its internal matters.

\section{Recommendations}

Due to the research limitations mentioned earlier, further improvement and refinement is needed in the future. For future research, the researchers recommend to increase the number and enrich the background difference of the interviewees, to enrich the data and minimize any biases.

\section{References}

Amann, B., Jaussaud, J., \& Martinez, I. (2011). Corporate Social Responsibility in Japan: Family and non-family business difeferences and determinants. Asian Business and Management, 329-345.

Asian Development Bank. (2015). Countries: Thailand and ADB. Retrieved 2015 йил December1 from Asian Development Bank: http://www.adb.org/countries/thailand/main

Astrachan, J. H., \& Jaskiewicz, P. (2008). Emotional Returns and Emotional Costs in Privately Held Family Businesses: Advancing Traditional Business Valuation. Family Business Review, 21 (2), 139-149. 
Berrone, P., Cruz, C., \& Gomez-Mejia, L. R. (2012). Socioemotional Wealth in Family Firms: Theoretical Dimensions, Assessment Approaches, and Agenda for Future Research. Family Business Review, 258-279.

Boardman, C. M., \& Kato, H. K. (2003). The Confucian Roots of Business Kyosei. Journal of Business Ethics, 48 (4), 317-333.

Brammer, S., Williams, G., \& Zinkin, J. (2007). Religion and Attitudes to Corporate Social Responsibility in a Large Cross-Crountry Sample. Journal of Business Ethics, 229-243.

British Broadcasting Company. (2015 йил 7-September). Indonesia Country Profile. Retrieved 2015 йил 30-November from BBC: http://www.bbc.com/news/world-asia-pacific- 14921238

Bruno, A., Jacques, J., \& Isabelle, M. (2011). Corporate social responsibility in Japan: Family and non-family business differences and determinants. Asian Business and Management, 329-345.

Campden FB. (2014 йил 5-22). Awards: TOP 60 FAMILY BUSINESS LEADERS 2014. Retrieved 2015 йил 20-10 from Campden FB: http://www.campdenfb.com/article/top60-family-business-leaders-2014

Cennamo, C., Berrone, P., Cruz, C., \& Gomez-Meija, L. R. (2012). Socioemotional Wealth and Proactive Stakeholder Engagement: Why Family-Controlled Firms Care More About Their Stakeholders. Entrepreneurship Theory and Practice, 36 (6), 1153-1173.

Charoen Pokphand Group. (n.d.). Shared Values. Retrieved 2015 йил 20-10 from Charoen Pokphand Group: http://www.cpgroupglobal.com/en/values.php?id=3\#values

Colombo, J. (2012 йил 4-June). Japan's Bubble Economy of the 1980s 30 Print Friendly. Retrieved 2015 йил 30-November from The Bubble Bubble: http://www.thebubblebubble. com/japan-bubble/

CT Corp. (2011). CT Foundation: Activities. Retrieved 2015 йил 3-December from CT Corp: http://www.ctcorpora.com/past.php

Deutsche Bundesbank. (n.d.). Service. Retrieved 2015 йил 30-November from Deutsche Bundesbank: https://www.bundesbank.de/Navigation/EN/Service/Glossary/Functions/ glossary.html?lv2=129554\&lv3=129236

Epstein-Reeves, J. (2010 йил 15-December). Forbes Magazine. Retrieved 2015 йил 16-5 from Forbes Magazine: http:/www.forbes.com/sites/teradata/2015/06/12/the-new-analyticsprofessional-landing-a-job-in-the-big-data-era/

Forbes. (2015). Indonesia's 50 Richest. Retrieved 2015 йил 13-8 from Forbes: http://www.forbes.com/indonesia-billionaires/

Friedman, M. (1962). Capitalism and Freedom. Chicago: The University of Chicago.

Gentile, F. (2014 йил 14-3). CORPORATE SOCIAL RESPONSIBILITY IN INDONESIA. Retrieved 2015 йил 1-8 from UBI Business: http://www.ubibusiness.com/topics/regulations/corporate-social-responsibility-regulation-in-indonesia-/\#.Vc2W_LdJDfI 
Global Reporting Initiative. (2015 йил 5-August). Sustainability Reporting Guidelines. Retrieved 2015 йил 26-April from Global Reporting Initiative: https://www.globalreporting.org/standards/g4/Pages/default.aspx

Godos-Diaz, J.-L., Fernandez-Gago, R., \& Martinez-Campillo, A. (2011). How Important Are CEOs to CSR Practices? An Analysis of The Mediating Effect of the Perceived Role of Ethics and Social Responsibility. Joural of Business Ethics, 531-548.

Gomez-mejia, L. R., Cruz, C., Berrone, P., \& Castro, J. D. (2011 йил 26-July). The Bind that Ties: Socioemotional Wealth Preservation in Family Firms. The Academy of Management Annals, 653-707.

Gomez-Mejia, L. R., Haynes, K. T., Nunez-Nickel, M., Jacobson, K. J., \& Moyano-Fuentes, J. (2007 йил January). Socioemotional Wealth and Business Risks in Family-controlled Firms: Evidence from Spanish Olive Oil Mills. ADMINISTRATIVE SCIENCE QUARTERLY, 106-137.

Gond, J.-P., Igalens, J., Swaen, V., \& El Akremi, A. (2011). The Human Resources Contribution to Responsible Leaderdship: An Exploration of the CSR-HR Interface. Journal of Business Ethics, 115-132.

Habisch, A., Jonker, J., Wagner, M., \& Schmidpeter, R. (2005). Corporate Social Responsibility Across Europe. Berlin: Springer.

Handoyo, S. S. (2010 йил 14-April). Shaping Governance in Indonesian Family Business. Retrieved 2015 йил 22-May from The Jakarta Post: http://www.thejakartapost.com/ news/2010/04/14/shaping-governance-indonesian-family-businesses.html

Hays, J. (2013). ECONOMIC HISTORY OF JAPAN IN THE 1970s AND 80s: RISE TO AN ECONOMIC POWERHOUSE AND THE BUBBLE ECONOMY. Retrieved 2015 йил 3011 from Facts and Details: http://factsanddetails.com/japan/cat24/sub155/item903.html

Hilal, A. A., \& Alabri, S. S. (2013). USING NVIVO FOR DATA ANALYSIS IN QUALITATIVE RESEARCH. International Interdisciplinary Journal of Education, 2 (2), 181-186.

Hirigoyen, G., \& Poulain-Rehm, T. (2014). The Corporate Social Responsibility of Family Business: An InternationalApproach. International Journal of Financial Studies, 240-265.

Ip, P. K. (2009). Is Confucianism Good for Business Ethics in China. Journal of Business Ethics, 463-476.

Kraisornsuthasinee, S. (2012). CSR Through the Heart of the Bodhi Tree. Social Responsibility Journal, 8, 186-198.

Lam, H., \& Khare, A. (2010). Hr's Crucial Role For Successful CSR. Journal of International Business Ethics, 3 (2), 3-15.

Latz, C. C. (2014). Rediscovering Shibusawa Eiichi in the 21st Century. Tokyo: Shibusawa Eiichi Memorial Foundation.

Low, P. K., \& Ang, S. L. (2013). Confucian Ethics, Governance and Corporate Social Responsibility. International Journal of Business and Management, 30-43. 
Lund Research. (2012). Research Strategy: Internal Validity. Retrieved 2015 йил 7December from Laerd Dissertation: http://dissertation.laerd.com/internal-validity.php

Maon, F., Lindgreen, A., \& Swaen, V. (2009). Designing and Implementing Corporate Social Responsibility: An Integrative Framework Grounded in Theory and Practice. Journal of Business Ethics , 71-89.

Nakamura, E. (2013). The Impact of Shareholders' Types on Corporate Social Responsibility: Evidence From Japanese Firms. Journal of Global Responsibility, 113130.

Nielsen. (2013 йил 8-June). DO CONSUMERS CARE ABOUT SOCIAL IMPACT. Retrieved 2015 йил 16-5 from Nielsen: http://www.nielsen.com/us/en/insights/news/2013/do-consumers-care-about-social-impact-.html

Oi, М. (2012 йил 25-December). In Japan, importance of family business opens up opportuinites. Retrieved 2015 йил 22-May from Marketplace: http://www.marketplace.org/topics/ world/bbc-world-service/japan-importance-family-business-opens-opportunities

Panjwani, A., Anggarwal, V., \& Dhameja, N. (2008 йил October). Family Business: Yesterday, Today, Tomorrow. Indian Journal of Industrial Relations.

Panjwani, A., Anggarwal, V., \& Dhameja, N. (2008 йил 10-January). Family Business: Yesterday, Today, Tomorrow. Indian Journal of Indsutrial Relation.

Pricewaterhouse Coopers. (2014). Global Annual Review 2014. Retrieved 2015 йил 10-February from PwC: http://www.pwc.com/gx/en/issues/megatrends/shift-in-global-economicpower-silas-yang.jhtml

PT Indofood Sukses Makmur TBK. (2015). Indofood Sukses Makmur's Scholarship. Retrieved 2015 йил 3-December from PT Indofood Sukses Makmur TBK: http://www.indofood. $\mathrm{com} /$ sustainability/building-human-capital/indofood-sukses-makmurs-scholarship-bisma

PT Indofood Sukses Makmur Tbk. (2015). Partnership With Farmers. Retrieved 2015 йил 3December from PT Indofood Sukses Makmur Tbk: http://www.indofood.com/sustainability/strengthening-economic-value/partnerships-with-farmers

PT Indofood Sukses Makmur Tbk. (2015). Protecting The Environment. Retrieved 2015 йил 3-December from PT Indofood Sukses Makmur Tbk: http://www.indofood.com/sustainability/protecting-the-environment

PT. Indofood Sukses Makmur Tbk. (2015). CSR: Overview. Retrieved 2015 йил 3-December from PT. Indofood Sukses Makmur Tbk: http://www.indofood.com/sustainability

Raharso, A. (2012). Family Business in Asia, Breaking the third generation curse. Hay Group. Singapore: Hay Group.

Sentana, I. M., \& Sudrajat, D. (2015 йил 5-November). Asia Economy. Retrieved 2015 йил 30-November from The Wall Street Journal: http://www.wsj.com/articles/indonesiasgdp-grows-4-73-in-3q-missing-market-expectations-1446705888 
Shapiro, D. M., Gedajlovic, E., \& Erdener, C. (2003). The Chinese Family Firm As A Multinational Enterprise. The International Journal of Organizational Analysis, 105122.

Sharma, B. (2010). Discovering The Asian Form of Corporate Social Responsibility. Singapore: Lien Centre for Social Innovation.

Srisuphaolarm, P. (2013). From Altruistic to Strategic CSR: How Social Value Affected CSR Development - A Case Study of Thailand. Social Responsibility Journal, 56-75.

Suzuki, W. (2014 йил 18-December). Magazine: Business. Retrieved 2015 йил 2-December from Nikkei Asian Review: http://asia.nikkei.com/magazine/20141218-MORE-MONEY-MORE-GUNS/Business/The-sky-s-the-limit-for-Indonesian-taxi-giant-Blue-Bird

Thanetsunthorn, N. (2014). Ethical Organization: The Effects of National Culture on CSR. Organization Development Journal, 89-109.

The World Bank. (2015). Countries: Thailand. Retrieved 2015 йил 1-December from The World Bank: http://www.worldbank.org/en/country/thailand

The World Bank. (2015). Data. Retrieved 2015 йил 30-November from The World Bank: http://data.worldbank.org/country/indonesia

Turyakira, P., Venter, E., \& Smith, E. (2012). Corporate Social Responsibility for SMEs: A Proposed Hypothesised Model. African Journal of Business Ethics, 6 (2), 106-119.

Unitated States Department of State. (n.d.). Occupation and Reconstruction of Japan. Retrieved 2015 йил 30-11 from Unitated States Department of State Office of The Histori- an: https://history.state.gov/milestones/1945-1952/japan-reconstruction

University of California, Los Angeles. (n.d.). What is Sustainability? Retrieved 2015 йил 3011 from UCLA Sustainability: http://www.sustain.ucla.edu/about-us/what-is-sustainability/

Valenti, A., Carden, L. L., \& Boyd, R. O. (2014). Corporate Social Responsibility and Businesses: Examining the Criteria for Effective Corporate Implementation Utilizing Case Studies . International Journal of Business and Socail Science, 5 (3), 1-14.

Virakul, B., Koonmee, K., \& McLean, G. N. (2009). CSR Activities in Award-Wining Thai Companies. Social Responsibility Journal, 5 (2), 178-199.

Wahyuni, S. (2015). Qualitative Research Method; Theory and Practice. Jakarta: Penerbit Salemba Empat.

Wartini, S., \& Heriyanto, D. S. (2014). Enhancing the Implementation of CSR in Developing Countries to Achieve Sustainable Development: Indonesian Perpspective. US-China Law Review, 1022-1041.

Wijaya, Y. (2008). The Prospect of Failism in the Global Era: A Study on the Recent Development of the Ethnic-Chinese Business, with Particular Attention to the Indonesian Con- text. Journal of Business Ethics, 311-317. 